\title{
Late presentation of lung sequestration
}

\author{
Khalid Alokla, ${ }_{1}^{1}$ Abdul Hamid Alraiyes, ${ }^{1}$ M Chadi Alraies ${ }^{2}$
}

${ }^{1}$ Department of Pulmonary Diseases, Critical Care \& Environmental Medicine Tulane University Health Sciences Center, New Orleans, Louisiana, USA ${ }^{2}$ Hospital Medicine, Cleveland Clinic, Cleveland, Ohio, USA

\section{Correspondence to} Dr M Chadi Alraies, alraies@hotmail.com

\section{DESCRIPTION}

A 35-year-old woman presented with a 4-month history of generalised body aches, fever, chills, pleuritic chest pain and cough productive of yellow sputum. She had history of multiple episodes of

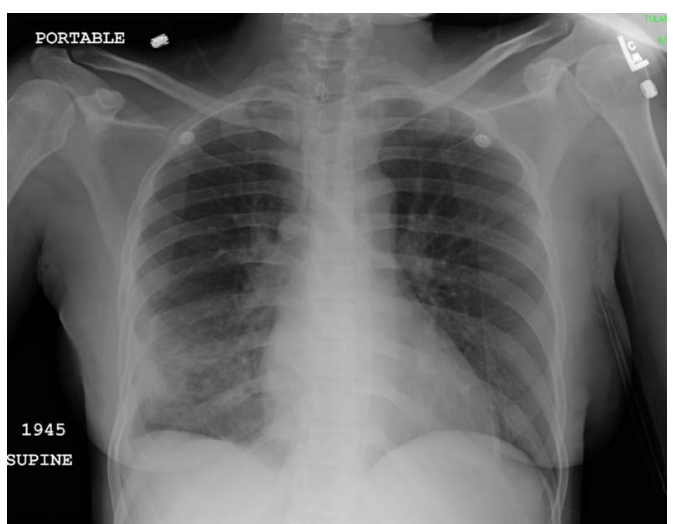

Figure 1 Chest radiograph showing airspace opacity within the right lower chest zone.
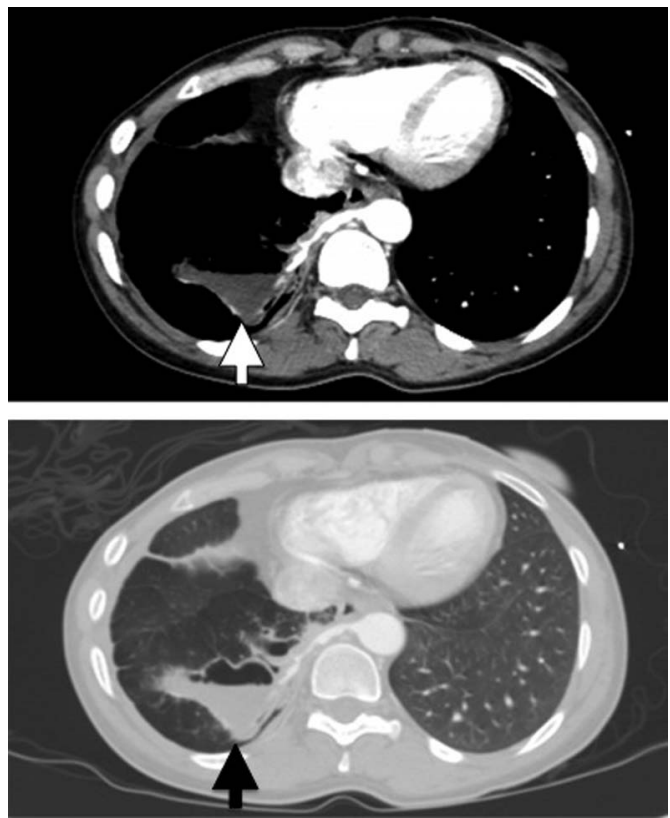

Figure 2 CT of the chest showing multiple cavitary lesions with air-fluid level supplied by an artery originating from the aorta (arrow). pneumonia treated with oral antibiotics with no improvement. She had 20 pack-years smoking history on bronchodilators. Extensive work was conducted including a skin purified protein derivative test, sputum acid-fast bacilli and HIV antibodies, which were all negative. On examination, the chest was remarkable for crepitations over the right lower lung zone. The rest of her examination was unremarkable. A chest radiograph showed airspace opacity within the right lower chest zone (figure 1). Sputum culture grew Streptococcus pneumoniae. CT of the chest revealed multiple cavitary lesions with air fluid level supplied by an artery originating from the aorta (figure 2). These findings were consistent with intralobar pulmonary sequestration presenting with frequent pulmonary infections. The patient underwent a right-lower lobectomy and the histology report revealed an acute neutrophilic pneumonitis supplied by elastic artery with intimal fibrosis.

\section{Learning points}

- Most patients with intralobar pulmonary sequestration (ILS) are asymptomatic.

- The diagnosis usually made after non-specific respiratory symptoms such as recurrent lobular pneumonia in the lower lung zones or haemoptysis. ${ }^{1}$

- In $85 \%$ of ILS cases, the arterial supply is arising from the infradiaphragmatic aorta.

- Treatment is mainly surgical with lobectomy. ${ }^{2}$

Contributors All authors had access to the manuscript and contributed equally in formatting and editing.

Competing interests None.

Patient consent Obtained.

Provenance and peer review Not commissioned; externally pee reviewed.

\section{REFERENCES}

1 Montjoy C, Hadique S, Graeber G, et al. Intralobar bronchopulmonary sequestra in adults over age 50: case series and review. W V Med J 2012;108:8-13.

2 Yucel O, Gurkok S, Gozubuyuk A, et al. Diagnosis and surgical treatment of pulmonary sequestration. Thorac Cardiovasc Surg 2008;56:154-7.

To cite: Alokla $\mathrm{K}$ 
Copyright 2013 BMJ Publishing Group. All rights reserved. For permission to reuse any of this content visit http://group.bmj.com/group/rights-licensing/permissions.

BMJ Case Report Fellows may re-use this article for personal use and teaching without any further permission.

Become a Fellow of BMJ Case Reports today and you can:

- Submit as many cases as you like

- Enjoy fast sympathetic peer review and rapid publication of accepted articles

- Access all the published articles

- Re-use any of the published material for personal use and teaching without further permission

For information on Institutional Fellowships contact consortiasales@bmjgroup.com

Visit casereports.bmj.com for more articles like this and to become a Fellow 